RESIDENT

\& FELLOW

SECTION

Section Editor

Mitchell S.V. Elkind,

MD, MS

B.J. Robottom, MD

W.J. Weiner, MD

Address correspondence and reprint requests to Dr. Bradley J. Robottom, Department of Neurology, University of Maryland School of Medicine, 110 S. Paca Street, 3-S-128,

Baltimore, MD 21201

Brobottom@som.umaryland.edu

\section{Teaching NeuroImages: \\ Rest tremor mimicking ventricular tachycardia}

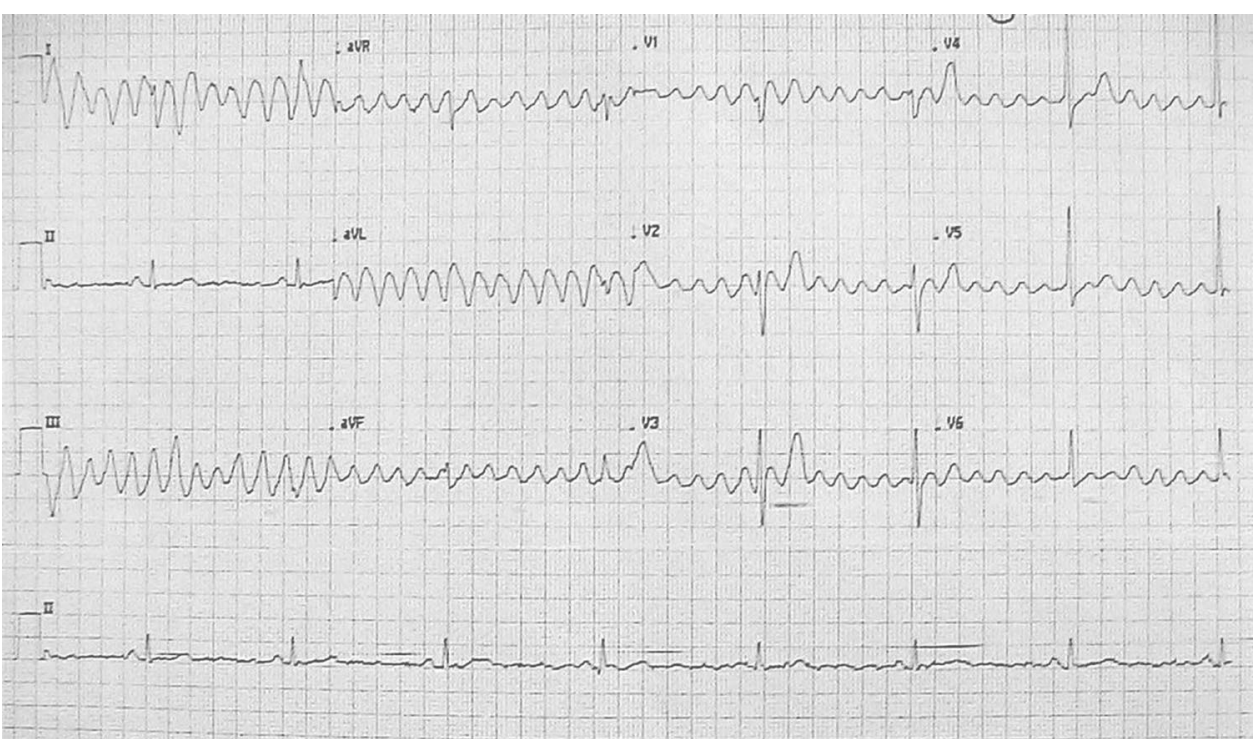

Artifact obscures QRS complexes in leads I, aVL, III, and aVF, giving the appearance of ventricular tachycardia. The normal QRS complexes in the rhythm strip rules out ventricular tachycardia, which would be present in all leads.

Ventricular tachycardia is a life-threatening condition. ECG artifact caused by the 4- to $6-\mathrm{Hz}$ rest tremor of Parkinson disease (PD) can mimic a wide complex ventricular tachycardia (figure). Misinterpretation of ECG artifact can have grave consequences, including cardiac catheterization, administration of antiarrhythmics, and placement of automated implantable cardioverter-defibrillators. ${ }^{1}$ Tremor artifact is most prominent in limb leads and represents the action potentials of striated muscle. Artifact in leads I, III, and aVL in this patient suggests left arm rest tremor. Holding the limb or placing electrodes on the chest can minimize this artifact. ${ }^{2}$ Neurologists should be aware of this ECG artifact to prevent unnecessary cardiac interventions.

\section{REFERENCES}

1. Bhatia L, Turner DR. Parkinson's tremor mimicking ventricular tachycardia. Age Ageing 2005;34:410-411.

2. Baranchuk A, Shaw C, Alanazi H, et al. Electrocardiography pitfalls and artifacts: the 10 commandments. Crit Care Nurse 2009;29:67-73.

From the Department of Neurology, University of Maryland School of Medicine, Baltimore.

Disclosure: Dr. Robottom receives research support from Chiltern International, Solvay/Abbott Pharmaceuticals, Inc., Westat, Inc., Elan Corporation, Medivation, Inc., and the University of Rochester/NINDS [subinvestigator]). Dr. Weiner has served on scientific advisory boards for Santhera Pharmaceuticals and Rexahn Pharmaceuticals, Inc.; serves on the editorial boards of Parkinsonism and Related Disorders and Neurological Reviews and as Editor of Treatment Options in Neurology; receives royalties from the publication of Neurology for the Non-Neurologist (6th edition, Kluwer/Lippincott, 2010), Parkinson's Disease: A Complete Guide for Patients and Family (2nd edition, Hopkins University Press, 2007), and Handbook of Clinical Neurology Hyperkinetic Disorders (Elsevier, 2011); has received honoraria from Santhera Pharmaceuticals and Novartis; has received research support from Novartis, Santhera Pharmaceuticals, and Boehringer Ingelheim; and has provided expert testimony and served as a subject matter expert in legal proceedings. 


\title{
Neurology
}

\author{
Teaching NeuroImages: Rest tremor mimicking ventricular tachycardia \\ B.J. Robottom and W.J. Weiner \\ Neurology 2010;75;2134 \\ DOI 10.1212/WNL.0b013e318200d7e6
}

This information is current as of December 6, 2010

Updated Information \&

Services

References

Subspecialty Collections

Permissions \& Licensing

Reprints including high resolution figures, can be found at: http://n.neurology.org/content/75/23/2134.full

This article cites 2 articles, 1 of which you can access for free at: http://n.neurology.org/content/75/23/2134.full\#ref-list-1

This article, along with others on similar topics, appears in the following collection(s):

\section{All Cerebrovascular disease/Stroke}

http://n.neurology.org/cgi/collection/all_cerebrovascular_disease_strok e

Other cerebrovascular disease/ Stroke

http://n.neurology.org/cgi/collection/other_cerebrovascular_disease_st roke

Parkinson's disease/Parkinsonism

http://n.neurology.org/cgi/collection/parkinsons_disease_parkinsonism

Tremor

http://n.neurology.org/cgi/collection/tremor

Information about reproducing this article in parts (figures,tables) or in its entirety can be found online at:

http://www.neurology.org/about/about_the_journal\#permissions

Information about ordering reprints can be found online:

http://n.neurology.org/subscribers/advertise

Neurology ${ }^{\circledR}$ is the official journal of the American Academy of Neurology. Published continuously since 1951, it is now a weekly with 48 issues per year. Copyright Copyright (? 2010 by AAN Enterprises, Inc.. All rights reserved. Print ISSN: 0028-3878. Online ISSN: 1526-632X.

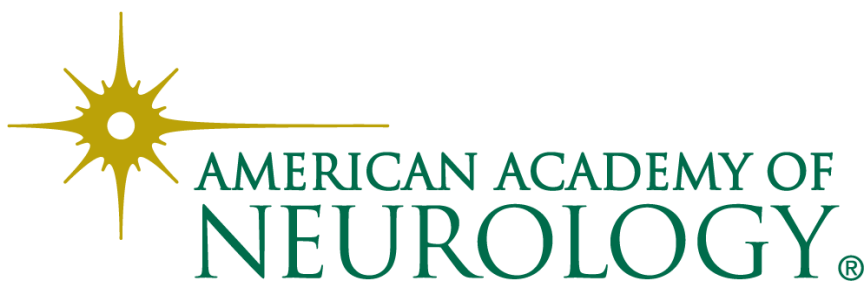

